\title{
Chromosome number of Elatine gussonei (Sommier) Brullo (Elatinaceae) and its distribution on the Maltese islands
}

\author{
Anna Kalinka $^{1 *}$, Stephen Mifsud ${ }^{2}$, AgnieszKa Popiela $^{3}$, Magdalena Achrem ${ }^{1}$ \\ ${ }^{1}$ Chair of Cell Biology, University of Szczecin, Waska 13,71-415 Szczecin, Poland \\ ${ }^{2}$ Environment Protection Directorate, Malta Environment Planning Authority, Malta \\ ${ }^{3}$ Department of Botany and Nature Conservation, University of Szczecin, \\ Felczaka 3c,71-412 Szczecin, Poland
}

\begin{abstract}
Elatine gussonei (Sommier) Brullo is an endemic species, with a distribution restricted to the central part of the Mediterranean Basin (Maltese islands, Lampedusa, southern part of Sicily). This hydrophyte grows in rainwater pools and cavities in karstic limestone. Although the morphology has been well studied, no karyological study has been carried out, and hence this work brings the first chromosome data for the Maltese-pelago endemic E. gussonei. We have found a diploid number of 54 chromosomes in E. gussonei, which differs from the chromosome number of most of Elatine species $(2 n=36)$. Additionally, this account gives a recent distribution of the species on the Maltese islands.
\end{abstract}

Key words: Elatine gussonei, chromosome number, phytogeography

\section{Introduction}

Elatinaceae Dum. is a small cosmopolitan family of herbaceous aquatic and semi-aquatic plants and terrestrial shrubs composed of two genera, i.e. Elatine L., comprising about 15-20 taxa, and occurring in areas of moderate temperatures in both hemispheres, and Bergia L., with about 25 species occurring mostly in tropical areas of the Old World, primarily in Africa, and also in Australia (TUCKER 1986, LEACH 1989). With regards to the genus Elatine, in Europe 10 species are acknowledged: E. triandra Schuhr., E. alsinastrum L.; E. hydropiper L.; E. orthosperma Dueben; E. hungarica Moesz.; E. macropoda Guss.; E. campylosperma Seub.; E. hexandra (Lapierre) DC; E. brochonii Clavaud and E. gussonei (Sommier) Brullo. Based on the arrangement of the leaves along the stem, NIEDENZU (1925, after SEUBERT 1845) proposed the subdivision of the genus Elatine into lower sub-

\footnotetext{
* Corresponding author, e-mail: akali@op.pl

Copyright $^{\circledR} 2014$ by Acta Botanica Croatica, the Faculty of Science, University of Zagreb. All rights reserved.
} 
genera: the subgenus Potamopithys (Adanson) Seub. (whorled leaves) and the subgenus Elatine (Hydropiper Moesz.) Seub. (opposite leaves). The latter subgenus includes two sections: Elatinella Seub., where the number of stamens is twice that of petals, and Triandra Seub. (= Crypta (Nutt. Seub.), characterised by an equal number of stamens and petals (TUCKER 1986). Elatine gussonei is one of eight species of the section Elatinella, one of which is found in Euroasia, six are found in Europe (three of them also in North Africa) and one in North America (California).

Elatine gussonei was first found and described by SOMMIER (1908) on the island of Lampedusa, under the taxon of Elatine hydropiper L. var. gussonei Sommier, based on color of corolla, the ratio in sizes of the flower parts and general seed morphology. Later, similar plants were also found in Malta. Both populations were reported to grow in rainwater pools contained in superficial small basins and cavities in karstic limestone (SOMMIER and CARUANA GATTO 1915), commonly known as rock pools. Much later, detailed morphological studies were carried out by BRULLO et al. (1988) resulted in the promotion of the taxon to species rank: Elatine gussonei (Sommier) Brullo, Lanfranco, Pavone and Ronsisvale. However the first record for the Maltese islands should be attributed to GRECH DELICATA (1853) who recorded Elatine macropoda Guss. from Wied Balluta, San Giljan. Since all local Elatine populations have been identified as E. gussonei, it is most probable that Grech Delicata (1853) also found E. gussonei - a species which is closely related to $E$. macropoda. Recently E. gussonei was also found in three localities in the south-eastern part of Sicily (MolnÁr et al. 2013).

The number of chromosomes in Elatine gussonei was not previously reported, in contrast to the unequivocal results of chromosome number for other species of the Elatine genus. The aim of this paper is to present results of the study on chromosome number of the taxon, as well as the new records of its distribution for the Maltese islands.

\section{Materials and methods}

The list of sites of Elatine gussonei and the distribution map for the Maltese are based on published (Borg 1927) and unpublished records by one of the authors.

Specimens were collected from 5 different populations in the Maltese islands and were immediately delivered to Department of Biology, University of Szczecin for karyological analysis supervised by three of the authors. Because it is a protected species, the necessary permits were obtained from the Malta Environment and Planning authority.

Roots were treated with $0.05 \%$ colchicine (Sigma-Aldrich, St. Luis, USA) solution for 3 hours, followed by a wash of $10 \mathrm{~min}$ with ice-cold distilled water. Then they were fixed in ethanol : glacial acetic acid, $3: 1(\mathrm{v} / \mathrm{v})$ for 24 hours at $4{ }^{\circ} \mathrm{C}$. Fixed roots were stored at $4{ }^{\circ} \mathrm{C}$ in fresh fixing solution. Roots were washed in distilled water, and under stereoscopic microscope the root tips were dissected. Each root tip was macerated directly on a microscope slide in a $10 \mu \mathrm{L}$ mixture of $4 \%$ (w/v) pectinase (Fluka, Buchs, Switzerland), 6\% (w/v) hemicellulase (Sigma-Aldrich, St. Luis, USA) and 4\% (w/v) cellulase (Sigma-Aldrich, St. Luis, USA) in $0.01 \mathrm{M}$ citric buffer for 2 hours at $37{ }^{\circ} \mathrm{C}$ in a humidity chamber. Root tips were carefully transferred with hypodermic needles to a drop of $45 \%$ acetic acid onto a new slide, and $10 \mu \mathrm{L}$ of $2 \%$ (w/v) aceto-orcein (Sigma-Aldrich, St. Luis, USA) were added. Each preparation was covered with a cover glass and stained at $47{ }^{\circ} \mathrm{C}$ for 1 hour. During this time aceto-orcein was added 3-5 times. The stain under a cover glass was 
replaced with $45 \%$ acetic acid. Root tips were squashed, and this was followed by gentle heating (5-10 min at $47^{\circ} \mathrm{C}$ ). Preparations were analyzed under an ECLIPSE E600 microscope (Nikon, Tokyo, Japan). Images were captured at $1000 \times$ magnification with CCD DS-Fi1c camera (Nikon, Tokyo, Japan) and analyzed by means of NIS-Elements AR3.1 (Nikon, Tokyo, Japan) software.

\section{Results and discussion}

\section{Phytogeographic study}

Elatine gussonei is in general well scattered throughout the rural areas of the Maltese islands, and therefore is not considered a locally rare species (Tab. 1, Fig. 1). It is specifically

Tab. 1. The list of localities of Elatine gussonei (Sommier) Brullo in the Maltase islands.

\begin{tabular}{|c|c|}
\hline Locality & References \\
\hline \multicolumn{2}{|l|}{ Mainland Malta: } \\
\hline Attard - Wied Incita & SOMMIER and CARUANA GATTO 1915 \\
\hline Birżebbuġa - Wied Hal-Saptan & SM, 2006* \\
\hline East of Ghar Hasan & SM, 2012* \\
\hline Gharghur - in-Nigret & SM, 2006* \\
\hline Mellieћa-Qammieћ & SM, 2006* \\
\hline Il-Miżieb & SM, 2006* \\
\hline 1-Imgiebah & SM, 2006* \\
\hline Coastal cliffs near Mistra area & SM, 2008* \\
\hline Mosta - Wied il-Ghasel & SOMMIER and CARUANA GATTO 1915 \\
\hline Tal-Wej & SM, 2006* \\
\hline Wied Filep & BORG $1927^{1}$ \\
\hline Rabat - Buskett Gardens & BORG 1927 \\
\hline Wied il-Girgenti & HASLAM and BORG 1998 \\
\hline Mtaћleb & SM, 2006* \\
\hline Sliema - Wied tal-Balluta & GRECH DELICATA 1853 \\
\hline San Ġiljan - Tal-Minsija & SOMMIER and CARUANA GATTO 1915 \\
\hline Harq hammiem & STEVENS 1995 \\
\hline Pembroke & SM, 2006* \\
\hline San Pawl il-Baћar - Rocky areas near Salini & SM, 2006* \\
\hline Sig̈giewi - Tal-Gћolja & BORG 1927 \\
\hline San Ġorg and Ġebel Ciantar area, limits of Fawwara & SM, 2010* \\
\hline Żurrieq - Wied il-Bassasa & SM, 2011* \\
\hline \multicolumn{2}{|l|}{ Gozo: } \\
\hline Munxar - Xlendi & SOMMIER and CARUANA GATTO 1915 \\
\hline Ras il-Fekruna & SM, 2007* \\
\hline Ta' Sannat - Ta' Ċenć & SOMMIER and CARUANA GATTO 1915 \\
\hline Wied Mġarr ix-Xini & SM, 2006* \\
\hline
\end{tabular}

* New records (= sites of E. gussonei not found in present literature)

${ }^{1}$ Demolished to make space for a stone quarry (from Wikipedia.org, accessed Jun 2012) 


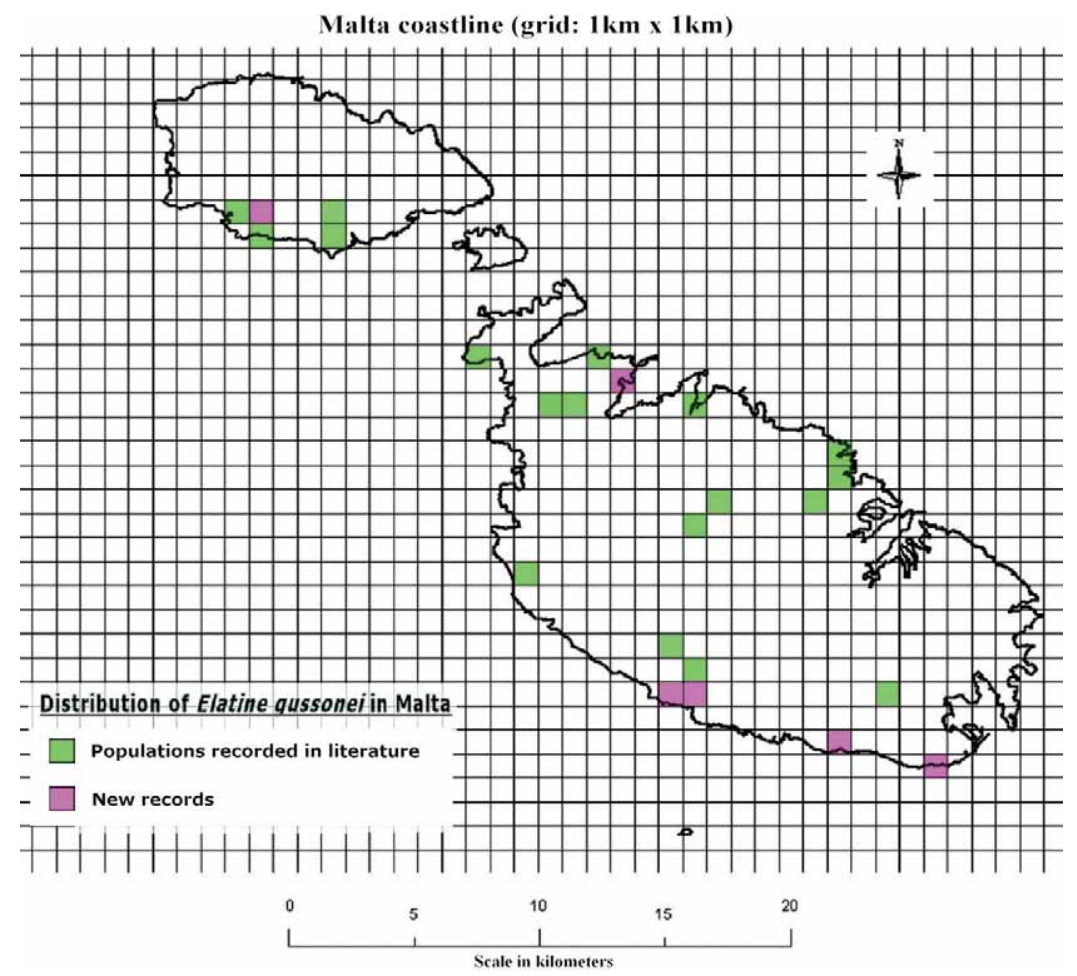

Fig. 1. Distribution of Elatine gussonei in the Maltese islands. (1 grid box $=1 \mathrm{~km})$.

and restrictedly found in rock pools scattered on coralline limestone mostly situated in rocky valley sides, borders of escarpments or coastal cliffs, and sometimes exposed, sloped rocky ground. Most natural rock-basins are not suitable to hold water for long and hence provide the habitat for E. gussonei because water seeps out through cracks and as a result they become void after few days without rain. However, the species often dominates suitable rock pools, forming a dense population composed of thousands of specimens. Among the species included in the section Elatinella, Elatine gussonei is the one most closely related to E. macropoda; a species mainly found in the western and central part of Mediterranean basin (POPIELA and ŁYSKO 2010). Many of the morphological differences used since SOMMIER (1908) to distinguish the two species appear to be somewhat unreliable. It turned out that the distinctive characters used by SOMMIER (1908) and SOMMIER et al.(1915) vary considerably according to environmental conditions and as a result they intersect between the species. It was proposed that more important distinguishing differences are the presence of a conspicuous semilunar membrane at the acute curvature of the seed and the shape and number of 'pits' in the reticulation of the seed testa (Molnár et al. 2013).

\section{Karyological analysis}

A total of 100 metaphase plates were analysed. Only well-spread metaphases were included in the study as overlapping chromosomes are the main cause of errors in determining the chromosome number (Fig. 2A). The chromosome number in E. gussonei amounts to 
$2 n=54$ (Fig. 2B). This count was confirmed through the detailed analysis of 30 metaphase plates. Chromosomes of Elatine gussonei are very small in size and for this reason the analysis was much more difficult than expected. Chromosomes of Elatine gussonei contain appreciable amount of heterochromatin, which is perfectly visible in the nuclei (Fig. 2C). However, the chromosomes are so small that it can hardly be stated if the condensed fraction of chromatin occupies the centromeric or telomeric part of chromosomes. It seems likely that at least in some chromosome pairs there are large blocks of heterochromatin in the subcentromeric region (Fig. 2D). This is the first report on chromosome number for this species. It was proposed that the basic number for Elatine genus is $\mathrm{x}=9$ (LöVE and LövE 1974, GoLDBLATT 1981, 1985). There are also several polyploid levels in different Elatine spp. such as tetraploids, octoploids and dodecaploids (UoTILA 1974). However, there are contradictory reports for chromosome numbers in the literature. For instance, CONTANDRIOPOULOS et al. (1987) reported that there are $2 \mathrm{n}=40$ chromosomes in Elatine macropoda Guss. The same chromosome number of $2 \mathrm{n}=40$ was reported for Elatine hydropiper $\mathrm{L}$. (LövE and LövE 1974). However, subsequent studies showed that chromosome number in this taxon is actually $2 n=36$ (KRAHULCOVÁ 1990). There is an indication that reports of $2 n=$ 40 probably refer to $2 \mathrm{n}=36$ (UоTILA 1974) and the counting error arises from the fact that the chromosomes of Elatine are very small and hence difficult to count precisely. In present paper the measurements of chromosomes from 30 metaphase spreads were made. The mean length of the chromosome was $0.69 \mu \mathrm{m}$, with a minimum value of $0.26 \mu \mathrm{m}$ and maximum

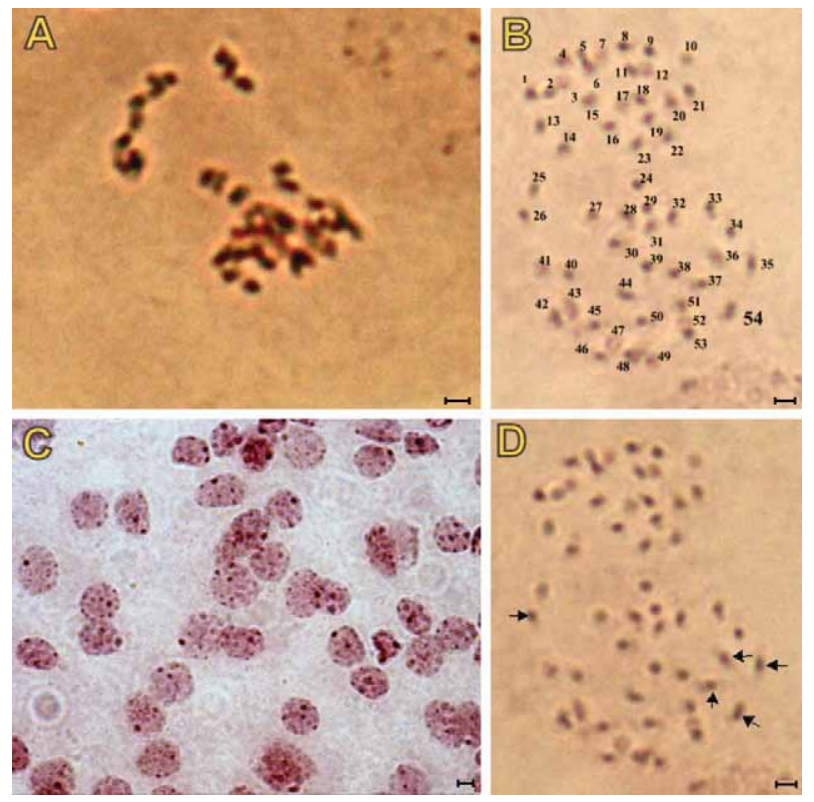

Fig. 2. Chromosomes and interphase nuclei of Elatine gussonei stained with aceto-orcein; A-metaphase spread with overlapping chromosomes, giving the false impression of 36 visible chromosomes; B - metaphase spreads with 54 chromosomes; $\mathrm{C}$ - interphase nuclei; dark spots correspond to condensed chromatin; D - metaphase spread; the condensed chromatin at centromeric / subcentromeric regions of some chromosomes are marked with arrows. Scale bar = $1 \mu \mathrm{m}$. 
value of $1.12 \mu \mathrm{m}(\sigma=0.17 \mu \mathrm{m})$. The same discrepancies appear in other species: Elatine americana (Pursh) Arn. 2n =70-72 (Probatova and SoKolovskAYA 1986), Elatine hexandra (Lapíerre) DC 2n = 72, 108 (JANKUn 1989, PogAn et al. 1990). The most common, as well as the lowest number of chromosomes in species of Elatine genus is $2 \mathrm{n}=36$ as was found in Elatine gratioloides A. Cunn. (DE LANGE et al. 2004) and Elatine triandra subsp. americana (Pursh) (LövE and LövE 1982).

\section{Acknowledgements}

This work was partially supported by the National Science Centre, Poland (project No: N N303 470638).

\section{References}

BorG, J., 1927: Descriptive flora of the Maltese Islands. Government Printing Office, Malta.

Brullo, S., Lanfranco, E., Pavone, P., Ronsisvalle, G., 1988: Taxonomical notes on the endemic flora of Malta. Giornale Botanico Italiano 122, 45.

Contandriopoulos, J., Noguet, D., Zevaco-Schmitz C., 1987: Contribution à l'étude dequelques espèces interessantes de Corse: cytotaxonomie et comportement écologique. Biologie-Ecologie Méditerranéenne 10, 259-271.

GoldBlatT, P., 1981: Index to plant chromosome numbers 1975-1978. In: GoldBLATT, P. (ed.), Monographs in systematic botany from the Missouri Botanical Garden, 5. Missouri Botanical Garden Press, St. Louis.

GoldBlatt, P., 1985: Index to plant chromosome numbers 1982-1983. In: GoldBlatt, P. (ed.), Monographs in systematic botany from the Missouri Botanical Garden, 13. Missouri Botanical Garden Press, St. Louis.

Grech Delicata, G. C., 1853: Flora melitensis, sistens stirpes phanerogamas in Melita Insulisque adjacentibus hucusque detectas secundum systema Candolleanum digestas Melitae. W. Franz Publishers, Malta.

JankUn, A., 1989: Further studies in chromosome numbers of Polish angiosperms. Part XXII. Acta Biologica Cracoviensia, Series Botanica 31, 1-17.

KrahulcovÁ, A., 1990: Selected chromosome counts of the Czechoslovak flora II. Folia Geobotanica and Phytotaxonomica 25, 381-388.

De Lange, P. J., Murray, B. G., Datson, P. M., 2004: Contributions to a chromosome atlas of the New Zealand flora, 38. Counts for 50 families. New Zealand Journal of Botany 42, 873-904.

LEACH, G. J., 1989: Taxonomic revision of Bergia (Elatinaceae) in Australia. Journal of the Adelaide Botanical Gardens 11, 75-100.

Löve, Á., Löve, D., 1974: Cytotaxonomical atlas of the Slovanian flora. Verlag Van J. Cramer, Lehre.

Löve, Á., Löve, D., 1982: In: LövE, Á. (ed.), IOPB chromosome number reports 75. Taxon $31,344-360$. 
Molnár, A. V., Popiela, A., Lukács, B. A.: Elatine gussonei (Sommier) Brullo (Elatinaceae) in Sicily. Plant Biosystems. In Press.

Niedenzu, F., 1925: Elatinaceae. In: Engler, A., Prantl, K. (ed.), Die Naturlichen Pflanzenfamilien, 2, 21, 270-276. W. Engelmann, Leipzig.

Pogan, E., Jankun, A., SAwickA, Z., 1990: Further studies in chromosome numbers of Polish angiosperms, part 22. Acta Biologica Cracoviensia, Series Botanica 31, 1-17.

Popiela, A., Łysko, A., 2010: The distribution of Elatine macropoda Guss. (Elatinaceae). Acta Societatis Botanicorum Poloniae 79, 81-86.

Probatova, N. S., Sokolovskaya, A. P., 1986: Chromosome numbers of the vascular plants from the far east of the USSR. Botanicheskii Zhurnal SSSR 71, 1572-1575.

SEubert, M., 1845: Elatinarum monographia. Academia Caesarea Leopoldino-Carolina Nova Acta 21, 34-60.

Sommier, S., 1908: Le isole pelagie Lampedusa, Linosa, Lampione e la loro flora. Stabilimento Pellas, Firenze.

Sommier, S., Caruana Gatto, A., 1915: Flora Melitensis Nova. Stabilimento Pellas, Firenze.

TUCKER, G. C., 1986: The genera of Elatinaceae in the southeastern United States. Journal of the Arnold Arboretum 67, 471-483.

UotilA, P., 1974: Elatine hydropiper L. aggr. in northern Europe. Memoranda Societatis pro Fauna et Flora Fennica 50, 113-123. 